Review Article

\title{
Anti-Trypanosomal Activities of Crude and Alkaloidal Fraction of Diospyros mespiliformis (African Ebony) Leaf on Trypanosoma Evansi Infected Rats.
}

\section{${ }^{1}$ Agbadoronye P.C, ${ }^{2}$ Abolarinwa, S.O, ${ }^{3}$ Oigbochie, V.E, ${ }^{1}$ Odeyemi, S.O, ${ }^{4}$ Irhue, A.E,} ${ }^{1}$ Ajunwa, L.O, ${ }^{1}$ Ubabu, Z.M, ${ }^{1}$ Ngamdu, S.A., ${ }^{1}$ Ifeanyichukwu, E. N

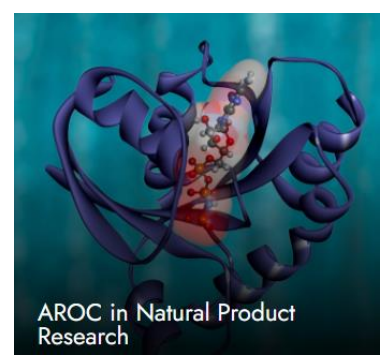

${ }^{1}$ Nigerian Institute for Trypanosomiasis Research, Suleja Outstation, Niger State, Nigeria.

${ }^{2}$ Department of Animal Biology, Federal University of Technology, P.M.B 65, Minna, Nigeria.

${ }^{3}$ Farm Project Faculty of Agriculture, University of Benin, Benin City, Nigeria.

${ }^{4}$ Nigerian Institute for Trypanosomiasis Research, South South Zonal Office, Asaba, Nigeria

\section{*Corresponding Author:}

Agbadoronye P.C: tasiepurity@gmail.com

Received: 21 May 2021, Revised: 24 June 2021, Published: 28 June 2021

\begin{abstract}
African trypanosomiasis is a parasitic disease that affects both humans and animals. This study investigated the antitrypanosomal activities of crude and an alkaloidal fraction of Diospyros mespiliformis in Trypanosoma evansi - infected rats. A total of twenty-one (21) albino rats were infected with Trypanosoma evansi and grouped into seven (A-G) of 3 rats each. Group A serve as normal control, groups B and C were given $0.2 \mathrm{ml}$ normal saline/ $\mathrm{kg}$ BW and $3.5 \mathrm{mg} / \mathrm{kg}$ BW diminazene aceturate respectively, groups D and E were treated with 100 and $200 \mathrm{mg} / \mathrm{kg}$ BW alkaloidal while groups $E$ and $F$ received crude extract at 200 and $400 \mathrm{mg} / \mathrm{kg}$ respectively for twelve days. Results revealed that both crude and an alkaloidal fraction of $D$. mespiliformis exhibited significant $(p<0.05)$ dose-dependent antitrypanosomal activities. The crude extract exhibited $54.55 \pm 3.04 \%(200 \mathrm{mg} / \mathrm{kg} \mathrm{BW})$ and $66.02 \pm 5.03(200 \mathrm{mg} / \mathrm{kg} \mathrm{BW})$ curative effect while the alkaloidal fraction exhibited better antitrypanosomal activities with $68.68 \pm 2.34 \%$ and $70.87 \pm 2.93$ curative effect at 100 and $200 \mathrm{mg} / \mathrm{kg}$ respectively. Furthermore, the crude extract prolonged the survival of the animals to $19.02 \pm 2.06(200 \mathrm{mg} / \mathrm{kg} \mathrm{BW})$ and $22.90 \pm 3.78(400$ $\mathrm{mg} / \mathrm{kg} \mathrm{BW}$ ) while the alkaloidal fraction at 100 and $200 \mathrm{mg} / \mathrm{kg}$ prolonged the survival of the mice to $23.45 \pm 1.24$ and 29.34 \pm 3.45 days respectively and improved the body weight gain of the animals when compared with the non-treated control (13.24 1.33 days). In conclusion, the leaves of Diospyros mespiliformis could be employed for the treatment of $T$. evansi infection as an alternative to conventional medicines that are besieged with undesirable properties.
\end{abstract}

Keyword: Diospyros mespiliformis; Trypanosoma evansi; Body weight; Survival period

Citations: Agbadoronye P.C, Abolarinwa, S.O, Oigbochie, V.E, Odeyemi, S.O, Irhue, A.E, Ajunwa, L.O, Ubabu, Z.M, ${ }^{1}$ Ngamdu, S.A., Ifeanyichukwu, E. N. (2021). Anti-Trypanosomal Activities of Crude and Alkaloidal Fraction of Diospyros mespiliformis (African Ebony) Leaf on Trypanosoma Evansi Infected Rats. AROC in Natural Products Research, 01(01); 61-69

\subsection{Introduction}

Medicinal Animal African Trypanosomiasis and human African trypanosomiasis are regarded as the major cause of rural poverty in sub-Saharan Africa because they wreak havoc on the health of humans and cattle that are supposed to be deployed for efficient farming [1]. The impact of tsetse transmitted trypanosome on gradual health decline in infected humans and livestock can never be over-emphasized [2]. In humans, the disease causes extreme fatigue, fever, swollen lymph nodes amongst others $[3,4]$. Particularly, the effect on livestock is alarming in the sense that meat and milk production is reduced, abortion rate and livestock death is on the increase [5]. Annual cattle and human death caused by trypanosomiasis in the sub-Saharan region is estimated at 3 million and 55,000 respectively $[1,2]$.

While the loss in livestock production and mixed farming alone is valued at 5 billion US dollars yearly in Africa $[3,6,7]$. Consequently, the

Citations: Agbadoronye P.C, Abolarinwa, S.O, Oigbochie, V.E, Odeyemi, S.O, Irhue, A.E, Ajunwa, L.O, Ubabu, Z.M, Ngamdu, S.A., Ifeanyichukwu, E. N. (2021). Anti-Trypanosomal Activities of Crude and Alkaloidal Fraction of Diospyros mespiliformis (African Ebony) Leaf on Trypanosoma Evansi Infected Rats. AROC in Natural Product Research, 01(01); 061-69 
livelihood of farmers who live in tsetse-infested regions is threatened since the enormous infected livestock cannot be used to plow the land nor the dead animals are used for meat [7].

Ineffectiveness of chemotherapy constitutes the greatest threat to the control of trypanosomiasis infection $[4,8,9]$. Therefore, to overcome this problem, new knowledge, tools, and products are urgently needed especially new drugs that are of importance [10]. New drugs against trypanosomiasis are urgently needed and the traditional methods of treatment using medicinal plants could be a promising source of new antitrypanosomal compounds $[11,12]$.

Members of the kingdom Plantae are used medicinally in different countries and are sources of many potent and powerful drugs [13]. Among several factors contributing towards the potential use of phytomedicine are safety, lack of adverse reactions and minimal side effects [14-16], which have been mostly found to particularly influence the use of such medicines in the treatment of infectious disease $[11,12,17]$ as most of the developing countries have adopted the traditional medical practice as an integral part of their culture $[18,19]$. However, the use of medicinal plants in modern medicine suffers from the fact that though hundreds of plants are used in the world to prevent or to cure diseases, scientific evidence in terms of modern medicine is lacking in some cases.

Diospyros mespiliformis Hoschst ex A. DC commonly known as African ebony is a large deciduous tree belonging to the family Ebenaceae in the order Ebenales found mostly in Tropical and Sub Saharan Africa [20]. It is a tall tree that grows up to 25 meters in height. It has a dense evergreen canopy. Diospyros mespiliformis has been used in Traditional Medical systems including Ayurveda, Chinese and African [21]. The plant is widely used in parts of Africa and a number of chemical constituents of therapeutic importance have been isolated $[22,23]$.

Diospyros mespiliformis is a traditional food plant in Africa, the fruit has the potential to improve nutrition. It is used as astringent, febrifuge, hemostatic, mild laxative, stimulant, and vermifuge and to facilitate childbirth. According to the literature, Diospyros mespiliformis has numerous pharmacological activities including; anticancer, analgesic, anti-microbial, antiinflammatory, hypoglycemic, antiplasmodial, and anti-oxidant [24-27]. Since D. mespiliformis is used for the treatment of many diseases in traditional medicinal systems [28],

Diospyros mespiliformis is readily available, inexpensive, less toxic, and affordable. Hence, the present study which evaluated the antitrypanosomal effect of the crude extract and alkaloidal fraction of Diospyros mespiliformis in albino rats was prompted by the claim of some traditional health practitioners that Diospyros mespiliformis is an effective remedy for the management, control, and treatment of trypanosome infection.

\subsection{Materials and Methods}

\subsection{Plant Collection and identification}

The leaves of $D$. mespiliformis were collected from the Kacha Local Government area of Niger State, Nigeria. The plant was identified and authenticated at the Department of Plant Biology, Federal University of Technology, Minna.

\subsection{Parasite}

Trypanosoma evansi was obtained from Nigerian Institute for Trypanosomiasis Research (NITR), Kaduna, Kaduna state, Nigeria. The parasite was maintained in the laboratory by serial passage in rats

\subsection{Experimental animals}

Adult Wister rats (Mean weight $=125.65 \pm 3.89$ g) were obtained from the animals hold unit of the Department of Biochemistry, Federal University of Technology Minna. The in vivo animal experiments were conducted in strict compliance with the principles for humane handling and use of laboratory animals as contained in the Animal Care Guidelines and Protocol Review of National Institutes of Health Guide for the Care and Use of Laboratory Animals.

\subsection{Ethics approval}

The animal experiment was conducted in strict compliances with the principles for humane handling and use of laboratory animals as contained in the Animal Care Guidelines and Protocol Review of National Institutes of Health Guide for the Care and Use of Laboratory Animals (NIH Publication No. 85-23, 1985) 


\subsection{Preparation and Extraction of plant material}

The carpels were rinsed under clean running water and air-dried for four weeks in the laboratory. The dried carpels were pulverized into a coarse powder with mortar and pestle, milled into a fine powder with an electric miller, and stored in a clean container till ready for use. Three hundred gram $(300 \mathrm{~g})$ of powdered $D$. mespiliformis leaf was weighed into a reflux flask (100 g per turn), 2.5 liters of methanol was used in succession and the extraction step was exhaustively carried out for two hours with a reflux extractor. The mixture was sequentially filtered with chess cloth and Whatman's paper (No.1). The final filtrate was first concentrated in a rotary evaporator and then later in a water bath at $65^{\circ} \mathrm{C}$. The dried extract was stored in a sample bottle in the refrigerator at $4{ }^{\circ} \mathrm{C}$.

\subsection{Extraction of Alkaloids}

The leaves of $D$. mespiliformis $(50 \mathrm{~g})$ powder were moistened with $200 \mathrm{~mL}$ of $95 \%$ ethanol, alkalified with $200 \mathrm{~mL}$ of ammonia solution, and macerated for $24 \mathrm{hrs}$ followed by extraction with ethanol. The ethanol extract was filtered, concentrated, and treated with $1.0 \mathrm{~N}$ hydrochloric acid. The filtrate was further alkalinified with ammonia solution and the alkaloid was obtained by fractionation in a separating funnel using chloroform $[29,30]$.

\subsection{In vivo Antitrypanosomal Assay}

A total of twenty-one (21) rats were divided into seven (7) groups of three (3) rats each.

Group 1: Uninfected and untreated

Group 2: Infected and untreated (negative control)

Group 3: Infected and treated with $3.5 \mathrm{mg} / \mathrm{kg}$ of berenil (standard control)

Group 4: Infected and treated with $100 \mathrm{mg} / \mathrm{kg}$ alkaloid fraction of mespiliformis

Group 5: Infected and treated with $200 \mathrm{mg} / \mathrm{kg}$ alkaloid fraction of mespiliformis

Group 6: Infected and treated with $200 \mathrm{mg} / \mathrm{kg}$ crude extract of mespiliformis.
Group 7: Infected and treated with $400 \mathrm{mg} / \mathrm{kg}$ crude extract of mespiliformis

\subsection{Determination of Parasitemia Count}

Evaluation of parasitemia was carried out by counting the number of parasites under the light microscope at $\times 40$ magnification from thin blood smear freshly obtained from the tip of the tail of the infected rats as described in previous studies $[31,32]$.

\subsection{Determination of Body Weight}

The body weight of each rat was measured before infection, after infection, and after treatment using an electronic weighing balance

\subsection{Data analysis.}

All analysis was conducted in triplicate and analyzed using statistical package for social science (SPSS) version 16 and presented as means \pm standard error of the mean. One-way analysis of variance (ANOVA) at $p<0.05$ was used for comparing the significant differences between treatment groups $(p<0.05)$.

\subsection{Results}

\subsection{Parasitaemia counts}

The effect of crude extract and alkaloidal fraction of Diospyros mespiliformis on $T$. evansi infected rats is shown in figure 1: The Infected untreated animals showed a progressive increase in parasitemia count throughout the study period. Rats treated with crude extract at 200 and 400 $\mathrm{mg} / \mathrm{kg} \mathrm{BW}$, and alkaloid fraction at 100 and 200 $\mathrm{mg} / \mathrm{kg} \mathrm{BW}$ of Diospyros mespiliformis significantly decreased the parasite multiplication in a dosedependent manner (Figure 1). Crude methanol extract of Diospyros mespiliformis exhibited $54.55 \pm 3.04 \%$ and $66.02 \pm 5.03 \%$ curative effect at 200 and $400 \mathrm{mg} / \mathrm{kg} \mathrm{BW}$ respectively while the alkaloidal fraction exhibited better antitrypanosomal activities and recorded $68.68 \pm 2.34 \%$ and $70.87 \pm 2.93$ curative effect at 100 and $200 \mathrm{mg} / \mathrm{kg}$ respectively. The standard drug however, produced $100 \pm 0.00 \%$ curative effect after a single administration (Table 1 ).

Citations: Agbadoronye P.C, Abolarinwa, S.O, Oigbochie, V.E, Odeyemi, S.O, Irhue, A.E, Ajunwa, L.O, Ubabu, Z.M, Ngamdu, S.A., Ifeanyichukwu, E. N. (2021). Anti-Trypanosomal Activities of Crude and Alkaloidal Fraction of Diospyros mespiliformis (African Ebony) Leaf on Trypanosoma Evansi Infected Rats. AROC in Natural Product Research, 01(01); 061-69 


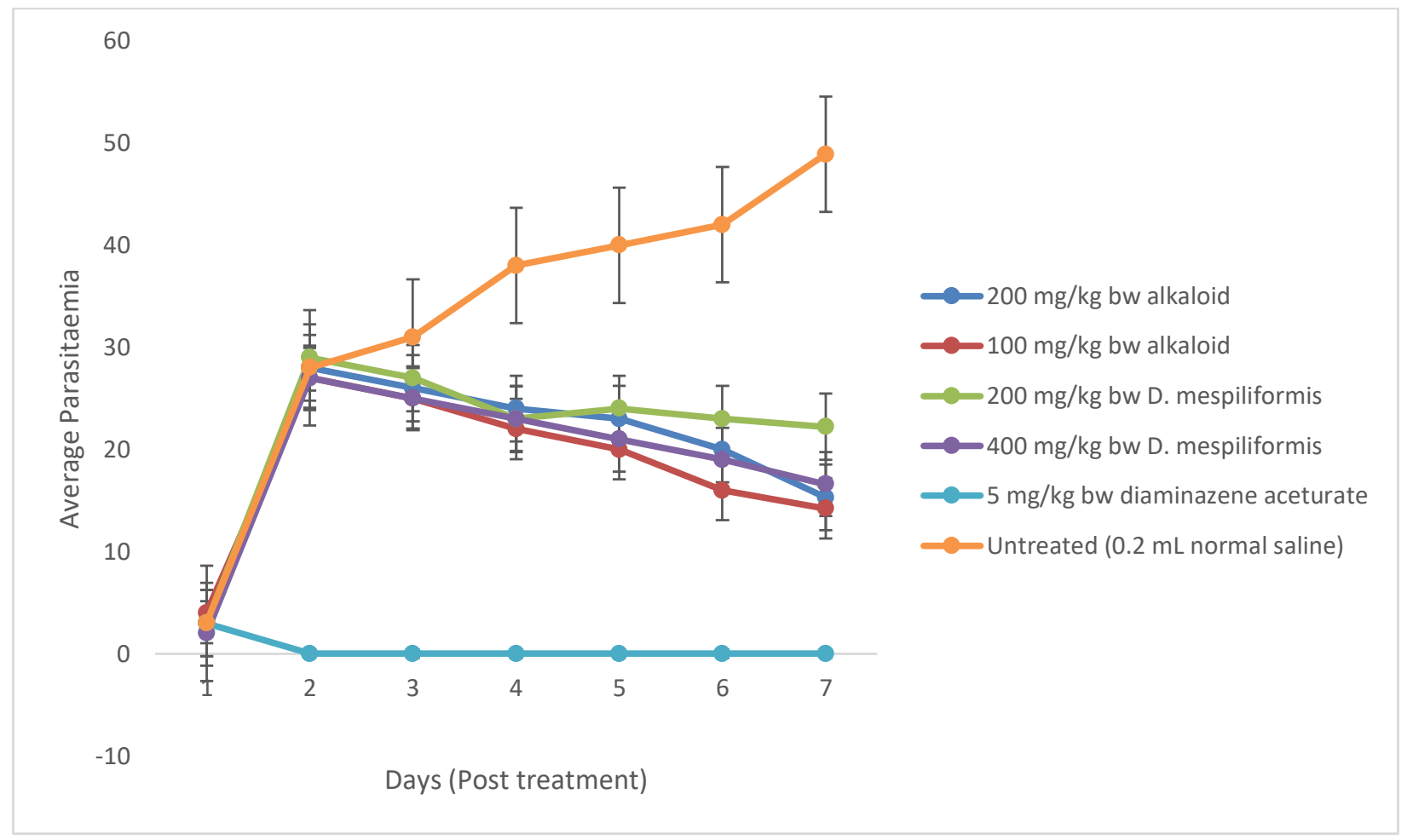

Figure 1: Effect of crude and alkaloidal fraction of Diospyros mespiliformis on parasitaemia count in T. evansi infected rats

Table 1: Curative effect and survival days of $T$. evansi infected rats treated with crude and alkaloidal fraction of Diospyros mespiliformis

\begin{tabular}{llcc}
\hline & $\begin{array}{c}\text { Average } \\
\text { parasitaemia }\end{array}$ & $\begin{array}{c}\text { Curative } \\
\text { effect (\%) }\end{array}$ & $\begin{array}{c}\text { Survival } \\
\text { days }\end{array}$ \\
\hline $100 \mathrm{mg} / \mathrm{kg}$ bw alkaloid & $15.31 \pm 0.76^{\mathrm{b}}$ & $68.68 \pm 2.34^{\mathrm{b}}$ & $23.45 \pm 1.24^{\mathrm{c}}$ \\
$200 \mathrm{mg} / \mathrm{kg}$ bw alkaloid & $14.24 \pm 0.89^{\mathrm{b}}$ & $70.87 \pm 2.93^{\mathrm{b}}$ & $29.34 \pm 3.45^{\mathrm{d}}$ \\
$200 \mathrm{mg} / \mathrm{kg}$ bw $D$. mespiliformis & $22.22 \pm 1.09^{\mathrm{c}}$ & $54.55 \pm 3.04^{\mathrm{a}}$ & $19.02 \pm 2.06^{\mathrm{b}}$ \\
$400 \mathrm{mg} / \mathrm{kg}$ bw D. mespiliformis & $16.61 \pm 0.89$ & $66.02 \pm 5.03^{\mathrm{b}}$ & $22.90 \pm 3.78^{\mathrm{bc}}$ \\
$5 \mathrm{mg} / \mathrm{kg}$ bw diaminazene aceturate & $0.00 \pm 0.00^{\mathrm{a}}$ & $100.00 \pm 0.00^{\mathrm{c}}$ & $60.00 \pm 0.00^{\mathrm{e}}$ \\
Untreated (0.2 mL normal saline) & $48.89 \pm 2.78^{\mathrm{d}}$ & - & $13.24 \pm 1.33^{\mathrm{a}}$ \\
\hline
\end{tabular}

Values are mean \pm SEM of 3 determinations. The values along the same row with different superscripts are significantly different $(p<0.05)$.

Citations: Agbadoronye P.C, Abolarinwa, S.O, Oigbochie, V.E, Odeyemi, S.O, Irhue, A.E, Ajunwa, L.O, Ubabu, Z.M, Ngamdu, S.A., Ifeanyichukwu, E. N. (2021). Anti-Trypanosomal Activities of Crude and Alkaloidal Fraction of Diospyros mespiliformis (African Ebony) Leaf on Trypanosoma Evansi Infected Rats. AROC in Natural Product Research, 01(01); 061-69 


\subsection{Survival Periods}

The alkaloidal fraction at 100 and $200 \mathrm{mg} / \mathrm{kg}$ prolonged the survival days of the mice to $23.45 \pm 1.24$ and $29.34 \pm 3.45$ days respectively when compared with the non-treated mice which survived for $13.24 \pm 1.33$ days only (Figure 2, Table 1). The crude extract also produced longer survival days of the animals to $19.02 \pm 2.06$ and $22.90 \pm 3.78$ days. However, mice treated with the standard drug (diminazene aceturate) had a longer survival day $(60.00 \pm 0.00$ days)

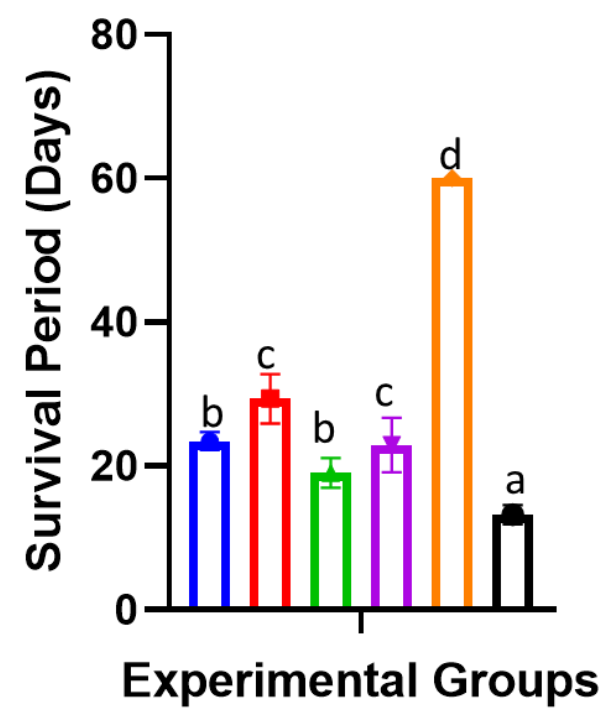

- $100 \mathrm{mg} / \mathrm{kg}$ BW Alkaloid

- $200 \mathrm{mg} / \mathrm{kg}$ BW Alkaloid

- $200 \mathrm{mg} / \mathrm{kg}$ BW Crude extract

v $4 \mathrm{mg} / \mathrm{kg} \mathrm{BW}$ Crude extract

- $5 \mathrm{mg} / \mathrm{kg}$ BW Diaminazee Aceturate

- Non treated control

Figure 2: Effect of crude and alkaloidal fraction of Diospyros mespiliformis on survival period of $T$. evansi infected rats. Each bars reperesent mean \pm SEM of 3 determinations. Bars with different superscripts are significantly different $(p<0.05)$.

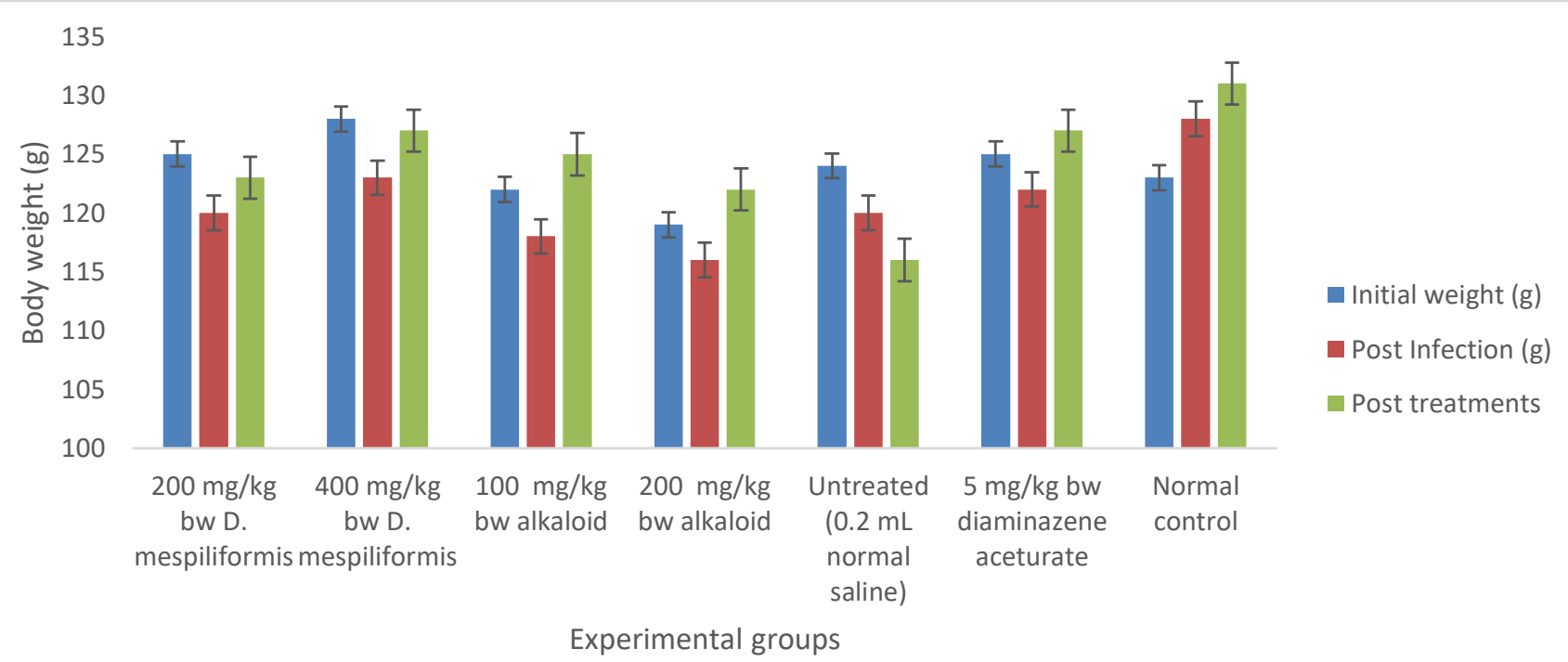

Figure 3: Effect of crude and alkaloidal fraction of Diospyros mespiliformis on body weight changes in $T$. evansi infected rats. Each Bars represent mean \pm SEM of 3 determinations.

Citations: Agbadoronye P.C, Abolarinwa, S.O, Oigbochie, V.E, Odeyemi, S.O, Irhue, A.E, Ajunwa, L.O, Ubabu, Z.M, Ngamdu, S.A., Ifeanyichukwu, E. N. (2021). Anti-Trypanosomal Activities of Crude and Alkaloidal Fraction of Diospyros mespiliformis (African Ebony) Leaf on Trypanosoma Evansi Infected Rats. AROC in Natural Product Research, 01(01); 061-69 


\subsection{Body weight}

The effect of crude and an alkaloidal fraction of Diospyros mespiliformis on body weight changes in $T$. evansi infected rats is shown in figure 3 . The bodyweight of all the experimental groups showed an initial decrease after $T$. evansi infection. However, groups of rats treated with crude extract at $400 \mathrm{mg} / \mathrm{kg} \mathrm{BW}$ and an alkaloidal fraction of Diospyros mespiliformis at 100 and $200 \mathrm{mg} / \mathrm{kg}$ BW significantly $(p<0.05)$ increased the body weight gain of the rats after treatments. Infected untreated rats showed progressive loss of body weight throughout the study period.

\subsection{Discussion}

Diospyros mespiliformis is a well-known and widely used medicinal plant in Africa for the treatment of various ailments [21]. Interestingly, the findings from the present study revealed that Diospyros mespiliformis exhibited remarkable activity against trypanosome evansi infection in rats. T. evansi produced an acute infection in inoculated rats as revealed by the progressive increase in parasitemia of infected and untreated rats.

It is, however, pertinent to mention here that methanol extract of Diospyros mespiliformis (200 and $400 \mathrm{mg} / / \mathrm{kg}$ ) and an alkaloidal fraction (100 and $200 \mathrm{mg} / \mathrm{kg}$ BW) significantly reduced the parasitemia. It is, therefore, reasonable to infer that Diospyros mespiliformis, potentially contains active constituents against $T$. evansi. Thus, these findings concur with ethnomedicinal uses of Diospyros mespiliformis for the treatment of HAT as reviewed by Ahmed and Mahmud, [21].

The prolonged survival days of rats treated with the alkaloid fraction could have probably been due to the antioxidants activities of alkaloids that scavenge the free fatty acids which are the initiators of the pathological effects of trypanosomiasis [33].

The promising antitrypanosomal potential shown by methanol extract of Diospyros mespiliformis leaf is further supported by the in vitro study by Christopher et al. [34] which reported that the plant extracts from members of the genus Diospyros exhibited $\mathrm{IC}_{50}$ values ranging from 1.28 to $7.85 \mu \mathrm{g} / \mathrm{ml}$ against the $T$. evansi parasite. Furthermore, Mbaya et al. [35] also reported that the Diospyros mespiliformis exhibited antitrypanosoma activities.

The negative influence of trypanosome infection on the bodyweight of the animals has been recognized and well documented [36]. Expectedly, $T$. evansi infection leads to significant loss of body weight, these losses were however significantly improved by treatment with an alkaloidal fraction of Diospyros mespiliformis. This can best be explained by the reduced pathological effect of the parasite and enhance physiological processes in animals during treatment with an alkaloidal fraction of Diospyros mespiliformis. Also, similar results obtained in other studies on parasitic protozoans revealed that methanol extracts of Diospyros mespiliformis also improve weight gain of P.berghei infected mice [37].

In our previous study, we reported that the alkaloidal fraction of Diospyros mespiliformis protects against Trypanosoma evansi-mediated hematological and hepatic impairment in infected rats [38]. Altogether, these studies justified the traditional use of Diospyros mespiliformis for the treatment of trypanosomiasis and other infectious diseases as well as the complication associated with those diseases.

\subsection{Conclusion}

The alkaloid fractions $(68.68 \pm 2.34$ and $70.87 \pm 2.93 \%$ curative effect) exhibited better antitrypanosomal activities at 100 and $200 \mathrm{mg} / \mathrm{kg}$ while the Crude methanol extract (54.55 \pm 3.04 and $66.02 \pm 5.03 \%$ curative effect) also exhibited antitrypanosomal activities at 200 and $400 \mathrm{mg} / \mathrm{kg}$ BW thus suggesting alkaloid to be the major antitrypanosomal agent in Diospyros mespiliformis. Therefore, the leaves of Diospyros mespiliformis could be employed for the treatment of $T$. evansi infection as an alternative to conventional medicines that are besieged with undesirable properties

Consent for publication: Not applicable

Availability of data and material: All data are presented in the manuscript

Competing interests: The authors declared no conflict of interest exist 
Funding: This study received no external funding

Authors' contributions: All authors participate in the execution of this project. All authors read and approved the final manuscript.

Acknowledgments: The authors would like to appreciate the technical staff of Biological Sciences and Biochemistry Laboratory Federal University of Technology Minna, for their kind assistance.

\section{References}

1. Büscher, P.; Cecchi, G.; Jamonneau, V.; Priotto, G. Human african trypanosomiasis. The Lancet 2017, 390, 2397-2409.

2. Brun, R.; Blum, J.; Chappuis, F.; Burri, C. Human african trypanosomiasis. The Lancet 2010, 375, 148-159.

3. Stich, A.; Abel, P.M.; Krishna, S. Human African trypanosomiasis. Bmj 2002, 325, 203-206.

4. Wellde, B.; Lötzsch, R.; Deindl, G.; Sadun, E.; Williams, J.; Warui, G. Trypanosoma congolense: I. Clinical observations of experimentally infected cattle. Experimental parasitology 1974, 36, 6-19.

5. Otesile, E.; Fagbemi, B.; Adeyemo, O. The effect of Trypanosoma brucei infection on serum biochemical parameters in boars on different planes of dietry energy. Veterinary

Parasitology 1991, 40, 207-216.

6. Steverding, D. The history of African trypanosomiasis. Parasites

vectors 2008, 1, 1-8.

7. Kumar, H.; Gupta, M.P.; Sidhu, P.K.; Mahajan, V.; Bal, M.S.; Kaur, K.; Ashuma; Verma, S.; Singla, L.D. An outbreak of acute Trypanosoma evansi infection in crossbred cattle in Punjab, India. Journal of Applied Animal Research 2012, 40, 256-259.

8. Bacchi, C.J. Chemotherapy of Human African Trypanosomiasis. Interdisciplinary Perspectives on Infectious
Diseases 2009, 2009, doi:10.1155/2009/195040.

195040,

9. Fairlamb, A.H. Chemotherapy of human African trypanosomiasis: current and future prospects. Trends in Parasitology 2003, 19, 488-494, doi:https://doi.org/10.1016/j.pt.2003.09 .002 .

10. Legros, D.; Ollivier, G.; GastelluEtchegorry, M.; Paquet, C.; Burri, C.; Jannin, J.; Büscher, P. Treatment of human African trypanosomiasis-present situation and needs for research and development. The Lancet Infectious Diseases 2002, 2, 437-440, doi:https://doi.org/10.1016/S14733099(02)00321-3.

11. Bashir, L.; Shittu, O.; Sani, S.; Busari, M.; Adeniyi, K. African natural products with potential antitrypanosoma properties: A review. Int J Biochem Res Rev 2015, 7, 45-79.

12. Lawal, B.; Shittu, O.K.; Kabiru, A.Y.; Jigam, A.A.; Umar, M.B.; Berinyuy, E.B.; Alozieuwa, B.U. Potential antimalarials from African natural products: A reviw. $J$ Intercult Ethnopharmacol 2015, 4, 318.

13. Ahmad, T.; Shahabuddin. The Uses of Medicinal Plants in the Treatment of Diseases. EUROPEAN ACADEMIC RESEARCH 2013, 1, 1850-1853.

14. Akanji, M.A.; Salau, A.K.; Yakubu, M. Safety evaluation of aqueous extract of Crateva adansonii leaves on selected tissues of rats. Fount J Nat Appl Sci 2013, 2, 17-28.

15. Bashir, L.; Shittu, O.; Busari, M.; Sani, S.; Aisha, M. Safety evaluation of giant African land snails (Archachatina maginata) haemolymph on hematological and biochemical parameters of albino rats. Journal of advances in medical and pharmaceutical sciences 2015, 122-130.

16. Lawal, B.; Shittu, O.K.; Oibiokpa, F.I.; Mohammed, H.; Umar, S.I.; Haruna, G.M. Antimicrobial evaluation, acute and subacute toxicity studies of Allium sativum. Journal of Acute Disease 2016, 5, 296-301. 
17. Lawal, B.; Shittu, O.K.; Oibiokpa, F.I.; Berinyuy, E.B.; Mohammed, H. African natural products with potential antioxidants and hepatoprotectives properties: a review. Clinical Phytoscience 2016, 2, 23, doi:10.1186/s40816-016-0037-0.

18. Arora, S.; Kaur, K.; Kaur, S. Indian medicinal plants as a reservoir of protective

phytochemicals. Teratogenesis, carcinogenesis, and mutagenesis 2003, 23, 295-300.

19. Iwu, M.M. African medicinal plants; CRC Press, Maryland: 1993.

20. Luka, J.; Badau, S.J.; Mbaya, A.W.; Gadzama, J.J.; Kumshe, H.A. Acute toxicity study and effect of prolonged administration (28 days) of crude ethanolic root extract of Diospyros mespiliformis Hochst (Ebenaceae) on clinical, haematological and biochemical parameters of albino rats. Journal of Ethnopharmacology 2014, 153, 268273,

doi:https://doi.org/10.1016/j.jep.2014.0 $\underline{2.033}$.

21. Ahmed, A.; Mahmud, A. Pharmacological activities of Diospyros mespiliformis: a review. Int J. Pharmacy Biol. Sci 2017, 7, 93-96.

22. Mohamed, I.E.; El Bushra, E.; Choudhary, M.I.; Khan, S.N. Bioactive natural products from two Sudanese medicinal plants Diospyros mespiliformis and Croton zambesicus. Records of Natural Products 2009, 3, 198.

23. Adzu, B.; Chindo, B.A.; Tarfa, F.D.; Salawu, O.A.; Igoli, O.J. Isolation and analgesic property of lupeol from Diospyros mespiliformis stem bark. Journal of Medicinal Plants Research 2015, 9, 813-819.

24. Adeniyi, B.; Odelola, H.; Oso, B. Antimicrobial potentials of Diospyros mespiliformis (Ebenaceae). African journal of medicine and medical sciences 1996, 25, 221-224.

25. Lajubutu, B.; Pinney, R.; Roberts, M.; Odelola, H.; Oso, B. Antibacterial activity of diosquinone and plumbagin from the root of Diospyros mespiliformis (Hostch)(Ebenaceae). Phytotherapy Research 1995, 9, 346-350.

26. Ndhlala, A.R.; Chitindingu, K.; Mupure, C.; Murenje, T.; Ndhlala, F.; Benhura, M.A.; Muchuweti, M. Antioxidant properties of methanolic extracts from Diospyros mespiliformis (jackal berry), Flacourtia indica (Batoka plum), Uapaca kirkiana (wild loquat) and Ziziphus mauritiana (yellow berry) fruits. International journal of food science \& technology 2008, 43, 284-288.

27. Adzu, B.; Salawu, O.A. Screening Diospyros mespiliformis extract for antimalarial potency. International Journal of Biological and Chemical Sciences 2009, 3.

28. Adzu, B.; Amos, S.; Dzarma, S.; Muazzam, I.; Gamaniel, K. Pharmacological evidence favouring the folkloric use of Diospyros mespiliformis Hochst in the relief of pain and fever. Journal of ethnopharmacology 2002, 82, 191-195.

29. Jigam, A.A.; Mahmood, F.; Lawal, B. Protective effects of crude and alkaloidal extracts of Tamarindus indica against acute inflammation and nociception in rats. Journal of Acute Disease 2017, 6, 78.

30. Adesina, D.A.; Adefolalu, S.F.; Jigam, A.A.; Lawal, B. Antiplasmodial effect and sub-acute toxicity of alkaloid, flavonoid and phenolic extracts of Sida acuta leaf on Plasmodium berghei-infected animals. Journal of Taibah University for Science 2020, 14, 943-953, doi:10.1080/16583655.2020.1790912.

31. Shittu, O.K.; Aaron, S.Y.; Oladuntoye, M.D.; Lawal, B. Diminazene aceturate modified nanocomposite for improved efficacy in acute trypanosome infection. Journal of Acute Disease 2018, 7, 36.

32. Shittu, O.; Lawal, B.; Oluyomi, O. Effects of methanol extract of Musca domestica larvae on antioxidants enzymes in $\mathrm{T}$. Brucei infected rats. Niger. J. Biochem. Mol. Biol 2014, 29, 1-10. 
33. Krieger, S.; Schwarz, W.; Ariyanayagam, M.; Fairlamb, A.; Krauth-Siegel, R.; Clayton, C. Trypanosomes lacking trypanothione reductase are avirulent and show increased sensitivity to oxidative stress. Molecular microbiology 2000, 35, 542-552.

34. Christopher, R.; Mgani, Q.A.; Nyandoro, S.S.; Rousseau, A.L.; van Vuuren, S.F.; Isaacs, M.; Hoppe, H.C. Antitrypanosomal, antiplasmodial, and antibacterial activities of extracts from selected Diospyros and Annonaceae species. Journal of Complementary Medicine Research 2018, 7, 161-170.

35. Mbaya, A.; Gyang, S.; Kumshe, H.; Onyia, I. Preliminary phytochemistry, toxicity and antitrypanosomal effects of methanolic extract of the root bark of Diospyros mespiliformis (Ebenaceae) on Trypanosoma brucei: an in-vivo and invitro study. Tropical Veterinarian 2010, 28, 1-12.

36. Payne, R.; Sukanto, I.; Bazeley, K.; Jones, T. The effect of Trypanosoma evansi infection on the oestrous cycle of
Friesian Holstein heifers. Veterinary parasitology 1993, 51, 1-11.

37. Oguche, M.; Nzelibe, $H$. In-vivo antiplasmodial activity of aqueous, nbutanol and ethylacetate fractions of leaf and stem bark methanol extracts of Diospyros mespiliformis on Plasmodium berghei berghei (Nk65) infected mice. International Journal of Biochemistry Research \& Review 2016, 1-9.

38. Agbadoronye P.C, Abolarinwa S.O, Lawal B, Odeyemi, S.O, Irhue, A.E, Achagwa, S.M, Ubabu, Z.M, Oigbochie, V.E, Ngamdu, S.A. Alkaloidal fraction of Diospyros mespiliformis protect against Trypanosoma evansi-mediated haematological and heapatic impairment in infected rats. BIOMED Natural and Applied Science, 2021, 1(1);66-78

\section{Submit your article to AROC JOURNALS \\ -AROC in Pharmaceutical and Biotechnology \\ -AROC in Agriculture \\ -AROC in Food and Nutrition \\ -AROC in Natural Product Research \\ -BIOMED Natural and Applied Science \\ Via https://arocjournal.com/}

Citations: Agbadoronye P.C, Abolarinwa, S.O, Oigbochie, V.E, Odeyemi, S.O, Irhue, A.E, Ajunwa, L.O, Ubabu, Z.M, Ngamdu, S.A., Ifeanyichukwu, E. N. (2021). Anti-Trypanosomal Activities of Crude and Alkaloidal Fraction of Diospyros mespiliformis (African Ebony) Leaf on Trypanosoma Evansi Infected Rats. AROC in Natural Product Research, 01(01); 061-69 